\title{
Fluorescence In Situ Hybridization Was Performed
}

National Cancer Institute

\section{Source}

National Cancer Institute. Fluorescence In Situ Hybridization Was Performed. NCI

Thesaurus. Code C160596.

An indication that fluorescence in situ hybridization was performed during the study. 